\title{
A Research on Social Media Use of the Youth Regarding Their Service Purchasing Behaviors
}

\author{
Ayşe Nevin SERT iD a \\ a Selçuk University, Beyşehir Ali Akkanat Faculty of Tourism, Konya, Turkey. nevinsert@selcuk.edu.tr
}

\begin{tabular}{ll}
\hline ARTICLE INFO & ABSTRACT \\
\hline Keywords: & $\begin{array}{l}\text { Purpose - Social media, which allows tourists to share travel experiences and communicate with other } \\
\text { people, has become the main source of information especially for young people when purchasing tourism- } \\
\text { related products and services. Tourism products and services are considered to be highly risky because } \\
\text { they cannot be evaluated in advance as material products and services. Therefore, the use of social media } \\
\text { has gained importance. The purpose of this study is to determine the social media usage of young people } \\
\text { Solated the tourism products and services and to determine social media involvement in social media } \\
\text { Digital Native }\end{array}$ \\
Selçuk University & $\begin{array}{l}\text { usage. } \\
\text { Design/methodology/approach - Data were collected with face-to-face survey technique from }\end{array}$ \\
participants. Reliability, Factor, Correlation and Regression tests were applied to the data set the help of \\
Revised 11 March 2020 \\
SPSS program.
\end{tabular}

\section{Introduction}

Social media is one of the fastest growing communication technologies in internet and tourism marketing (Xiang and Gretzel, 2010; Kang and Schuett, 2013; Bilgihan, Barreda, Okumus and Nusair, 2016. Stakeholders of the tourism industry are frequently found on numerous platforms such as Twitter, Facebook, Instagram, Pinterest, Vine, Snapchat, Twitter and Google. Therefore, it can be argued that online social networks are the main basis of the digital marketing strategy for the tourism industry. The impact of social media on the tourism industry can also be measured by the increase in comments on tourism products and services on social media platforms. For example, on TripAdvisor, 320 million comments are shared by approximately 96 million members worldwide (Ukpabi and Karjaluoto, 2017) which are estimated to affect online tourist products and services purchases worth more than $\$ 10$ billion annually (Bilgihan et al., 2016).

The emergence of social media (Kaplan and Haenlein, 2010) which allows users to create and share content with videos, photos and texts through internet applications based on the intellectual and technological foundations of Web 2.0, has changed consumer behavior and marketing approaches on the web considerably (Ayeh, Au and Law, 2013). Social media affects consumer behavior in terms of awareness, knowledge, opinion, involvement, purchase and post-purchase communication and evaluation (Fotis, Buhalis and Rossides, 2011). Social media contributes to the formation of knowledge while changing the consumption habits of society (Xiang and Gretzel, 2010; Hays, Page and Buhalis, 2013). People want to obtain impartial and reliable information to make informed decisions about destinations, accommodation establishments, restaurants, tours, tourist attractions and so on (Xiang and Gretzel, 2010; Kang and Schuett, 2013). Tourism products and 
services are considered risky because they cannot be evaluated in advance like material products and services. Therefore, the personal recommendations shared by those who have experienced them before are quite effective Amaro, Duarte and Henriques, 2016). At this point, social media plays an important role in reducing the risk before travel by providing ideas and facilitating the imagination of what kind of place it is $(\mathrm{Kim}, \mathrm{Qu}$ and Kim, 2009; Amaro et al., 2016). For example, the fact that tourists share their real experiences at a destination enables potential tourists to compare their own perceptions with the actual experience and consequently change their risk perceptions (Sirakaya and Woodside, 2005; Kim et al., 2009).

Social media which has an impact on every area in life affects the present day younger generations who are open to virtual structuring, innovations and changes outside the traditional areas more and young people put these technologies into the center of their lives. The young people who are different from their predecessors are 'digital natives' born into an environment established by new technologies (Armağan, 2013; Cohen, Prayag and Moital, 2014). It is important to identify the social media use of young people who make up a segment that cannot be ignored by the tourism industry.

Studies on social media use of young people (Junco, 2012; Lenhart, 2013; Armağan, 2013) have been carried out, however studies on the effects of social media involvement and the effects of this involvement on social media use are limited. The aim of this study is to determine the use of social media of young people in the consumption of tourism products and services and to determine the effect of social media involvement of young people on social media usage behavior.

\section{Literature Review}

Social media has radically influenced the way society forms and disseminates information and has changed both the demand (consumer decision-making process) as well as the supply-side structure of the tourism industry (Uşaklı, Koç and Sönmez, 2017). It can be said that social media platforms have made it necessary to revise the basic assumptions about the purchasing process. In the past, marketers assumed that consumers initiated the procurement process with a large number of options in their minds and systematically eliminated those options until they reached a decision and after the purchase they generally focused on the use of the products or services. However, with the emergence of social media, a more complex and different view has been manifested about how consumers interact with brands (Hudson and Thal, 2013). In their study Court, Elzinga, Mulder and Vetvik (2009) determined that instead of systematically reducing the options in their minds until they decided what to buy, consumers added and rejected options that they had not considered at all and that they shared their experiences mainly through social media after the purchase procedure.

Social media users around the world have approached approximately 3.2 billion people. Users often check their accounts during the day. For example, Facebook users access their accounts 5 times per day on average (Global Social Media Research, 2018). This has significantly affected the tourism industry as it has other industries, and has changed the way people search, find, read, and share their post-holiday experiences (Leung, Law, van Hoof and Buhalis, 2013; Chung, and Koo, 2015; Ukpabi and Karjaluoto, 2017). Especially since tourism is a 'knowledge-intensive industry', social media is becoming more important (Xiang and Gretzel, 2012; Hays et al., 2013). Tourism products and services are generally considered to be high-risk purchases since they cannot be assessed before consumption (Kim et al., 2009) and therefore risk reduction is made through comprehensive information search (Srakaya and Woodside, 2005; Fotis et al., 2011). Individuals have to leave the habitats that they are familiar with and go to a different place that they do not know in order to consume tourism products and services and while they are doing this they are equipped with only some unclear information. Consumers cannot try out their touristic products and services before they buy, and they cannot know whether the actual experience will be worth the money they paid for it or had to endure (Kim et al., 2009). In this context, obtaining information reduces the existing uncertainty. Chung and Buhalis (2008) suggested that acquisition of information is the most important factor affecting social media use. Approximately 95\% of Internet users search for information on the Internet before traveling and use social media (Pan and Fesenmaier, 2006).

It can be said that it is very important for the tourism industry to understand how consumers search, evaluate, and make decisions at various stages of the travel process. Generally, the use of social media for travel is divided into three stages: before, during and after travel (Kheiri and Nasihatkon, 2015; Amaro et al., 2016). The pre-travel period is about familiarization and information seeking, social media is used to search for 
information about potential destinations, transportation options, accommodation and activities available at the destination. Tourism products and services are consumed during travel. At this stage, the use of social media by travelers seems to decrease compared to the pre-travel phase. The 'post travel' stage is the evaluation stage and the use of social media reaches the highest level (Cox, Burgess, Sellitto and Buultjens, 2009). People often post personal recommendations, comments, satisfaction or dissatisfaction levels, photos, videos etc. through social media after traveling. However, in order to reduce uncertainty, it has been determined that social media is used mainly for information gathering before traveling (Cox et al., 2009; Fotis et al., 2012). According to Kheiri and Nasihatkon (2015), social media is used the most before travel and the least after travel.

In addition to gaining knowledge, social media creation and content generation are effective on tourism products and services (Chung and Koo, 2015). Social media plays an important role as a platform for personal travel stories, comments, warnings, advice / tips and suggestions that affect travel decisions and even form the first image of a destination. Information shared on social media sites is considered as an important source of information that can affect travel decisions for potential tourists (Kang and Schuett, 2013). Chung and Koo (2015) stated that social media is used for information gathering rather than sharing information and generating content. According to the authors, $79.8 \%$ of the users only researched while $61.2 \%$ shared, $36.2 \%$ commented and only $24.2 \%$ generated content. In the pre-travel period people read the comments on social media and examine photographs. However, they do not share content (comments, suggestions) (Amaro et al., 2016) and their participation is passive (Cox et al., 2009; Fotis et al., 2012). Generating content and sharing while traveling becomes more active. At this stage, travelers start to share their travel experiences by uploading visual content (photos, videos) (Cox et al., 2009).

In their study Fotis et al. (2012) indicated that during travel people used social media to communicate with friends at a rate of $50 \%$ while $30 \%$ used it to search for information about activities that can be done. At this stage it was determined that the exchange of comments and information was low at a rate of $16 \%$.

Finding or sharing information as well as content generation is also about how social media is perceived. At this point, enjoyment / liking is an important factor affecting the use of social media (Ayeh et al., 2013). Perceived enjoyment refers to the degree to which the activity of using a particular technology is perceived to be enjoyable on its own, without consideration for the instrumental value and functionality of the technology. Perceived pleasure is considered to be an important factor explaining a certain behavior in information and communication technologies such as adopting and using technology (Kang and Schuett, 2013). Research has shown that, in addition to the informative benefits of social media, reading about the experiences of other people on holiday makes the travel planning process more enjoyable and the prospective travelers become more excited and curious (Chung and Buhalis, 2008; Gretzel, 2012). Ayeh et al. (2013) found a positive relationship between perceived enjoyment and the tendency to use social media in travel planning. It is suggested that perceived enjoyment not only affects the use of social media in travel planning but also affects travel sharing (Ayeh et al., 2013; Amaro et al., 2016). Enjoying using social media seems to increase travelrelated content creation and sharing. Reasons such as enjoying social media content, interaction with other members ensures that social media is perceived as fun. The perception that the use of social media is pleasant increases the time and frequency of social media use (Kang and Schuett, 2013).

Whether the use of social media is enjoyable or not, whether it is a reliable source of information or not is a subject to be examined (Hyung-Park Lee and Han, 2007; Fotis et al., 2012; Kang and Schuett, 2013). Consumers are more inclined to find comments from other consumers who they think provide more honest information on social media more reliable than the information provided by products and service providers (Hyung-Park et al., 2007). Kang and Schuett (2013) suggest that travel information generated by users on social media, shared travel experiences is generally considered more reliable than information provided by tourism organizations and private sector enterprises. However, Fotis et al. (2012) indicated that users were more skeptical about taking the advice of strangers on social media that they do not know and preferred to rely on the recommendations of known and trusted people (friends, colleagues, etc.). In the study of Fotis et al. (2012) friends and relatives were found to be the most reliable sources, while social media ranked third. In their study, Cox et al. (2009) determined that official tourism sites were considered the most trustworthy while friends and relatives ranked second and social media took third place. The authors stated that potential tourists were more confident in the recommendations of friends, family and other peer groups, especially when 
planning a travel to a destination that they had not visited before (Cox et al., 2009). The assumption is that social media will be perceived as a reliable source and will have a positive impact on involvement for travel planning purposes and the usefulness of content (Ayeh et al., 2013).

Another factor that is thought to affect the use of social media is involvement. Involvement in social media encompasses general interest, commitment and point of view in terms of travel-related social media. Involvement can be defined as the degree of interest in social media use, the meaning attributed to social media (Chang, Chou, Yeh, and Tseng, 2016). It is observed that people with high interest and commitment to social media are more likely to share their travel experiences on social media and have higher levels of social media use (Chang et al., 2016; Amaro et al., 2016).

Another issue that stands out in the use of social media for tourism purposes is young people. Social media has become an indispensable tool used by young people in every area of their lives and they use social media for traveling like they do in other areas (Liberato, Liberato, Abreu, Alén-González and Rocha, 2018). In recent years, tourism has become a frequent leisure activity for young people, thus young people constitute an important market segment for the tourism sector. Young people have grown up in a globalized world, in the digital age, and in an era when knowledge has been subject to radical changes and sudden developments (Pendergast, 2010; Liberato et al., 2018). Today's young people are the first generation born into the information age and are therefore called "digital natives" (Pendergast, 2010). The important characteristics of young people are that they have been introduced to technology early and use it intensively. This situation creates advantages and disadvantages for young people in terms of cognitive, emotional and social outcomes. For example, they rely most on technology for entertainment, interacting with others and even regulating their moods (Bolton et al., 2013). The most important factor in young people's adoption of social media is that it provides an environment where they can act completely independently and without restriction. According to the structure of social media, the control of communication is completely given to the user, young people can behave as they wish, they can configure and maintain all processes of communication themselves, they are free to decide with whom, when and under what conditions they will communicate (Durmuş, 2014).

Young people value the thoughts of others in social media and enjoy providing feedback about the products and services they use and thus feel important about themselves (Bolton et al., 2013). Young people use social media to get more information, as a leisure activity, entertainment, socialization, a sense of belonging to a community, and communication with friends (Lenhart, 2013; Bolton et al., 2013, Ng, 2016). The study carried out by Armağan (2013) revealed that $96.8 \%$ of youth used social media and $71 \%$ spent 1 to 5 hours on social media sites. Various studies (Vural and Bat, 2010; Junco, 2012; Armağan, 2013; Erol and Hassan, 2014) that have been carried out shows that young people use social media as a communication tool to share pictures, videos, music, information, research a subject, to share thoughts and comments with friends. As the determination of the preferences and behaviors of young people is considered important for tourism stakeholders, the study aimed to reveal the social media usage and involvement of young people in terms of travel.

The following hypotheses have been developed with regard to social media use and involvement in line with the reviewed literature:

$\mathrm{H}_{1}$ : Social media involvement affects social media consumption.

$\mathrm{H}_{2}$ : Social media involvement affects trust in the travel information source.

$\mathrm{H}_{3}$ : Social media involvement affects the social media creation.

$\mathrm{H}_{4}$ : Social media involvement affects the perceived pleasure in social media usage. 


\section{Method}

The main body of the study was composed of the students of Beyşehir Ali Akkanat Tourism Faculty and Beyşehir Ali Akkanat Vocational School of Selçuk University. The respondents in this study were selected by means of convenience sampling which is one of the non-random sampling methods by using the students studying in the faculty and vocational schools used as the basis of the main body.

In order to achieve the aim of the study, a survey was applied to 250 students out of the total of 1.138 students of Beyşehir Ali Akkanat Tourism, Business Administration and Applicable Sciences Faculty and 200 students from Beyşehir Ali Akkanat Vocational School, which has 2,360 students. The study started in October 2018 and was completed in November of the same year. The application was carried out using a face to face survey method. 450 questionnaires were returned as a result of the application. 37 of the 450 questionnaires were not evaluated because they did not have sufficient data and significance. The lack of sufficient data and significance arises in the absence of an answer to all of the questions posed in the questionnaires or when random markings are made without reading. 413 questionnaires with sufficient data were included in the study.

A 3-part questionnaire was used as a data collection technique in the study. In the first part, the social media usage scale consisting of 17 statements was used to measure the social media usage of the respondents regarding traveling. The studies of Amaro et al. (2016) and Fotis et al. (2011) were used in the establishment of this scale. A social media involvement scale consisting of 7 expressions adapted from the study of Amaro et al. (2016) was used in the second part of the survey. Each item in the scales was graded with a 5-point Likert type scale and scored as Strongly disagree $=1$ and Strongly agree $=5$. The third part consisted of questions determining demographic features, gender, age, educational status of the respondents, the social media sites they are members of and their daily social media usage times. The questionnaire form was initially applied to 40 people. The data obtained from this pilot study conducted in October 2018 were analyzed with SPSS 22.0, a statistical package program developed for social sciences, and it was determined that the measurement tool provided reliability and validity (Cronbach's alpha value 0.830 ).

The data obtained from the respondents were covered by descriptive and inferential statistics within the scope of the study. The frequency distributions that determine the demographic characteristics of the individuals were obtained first in the study. Subsequently, the respondents' tendencies regarding social media use and social media involvement were tested. Reliability, Factor, Correlation and Regression tests were applied to the data set. Cronbach's Alpha Coefficients were used to test the reliability of the scales. This was followed by factor analysis to ensure the validity of the scales. The correlation test was used to determine the linear relationship between two independent variables or the relationship of a variable with two or more variables and the degree of this relationship, if any. Regression analysis was also used to measure the cause-effect relationship between an independent variable and a dependent variable, or between more than one independent variables and a dependent variable.

\section{Findings}

\subsection{Demographic Characteristics}

The demographic characteristics of the respondents are given in Table 1. According to Table 1,59.6\% of the respondents were female and $40.4 \%$ of them were male. An examination of the age groups shows that $52.1 \%$ were between 21 and 25 years of age, $41,4 \%$ were 20 and under and $6.5 \%$ were in the $26-30$ age interval. 
A. N. Sert $12 / 1(2020) 557-570$

Table 1. Demographic characteristics of the respondents

\begin{tabular}{lccc}
\hline Variables & Groups & Number & Percentage (\%) \\
\hline \multirow{2}{*}{ Gender } & Female & 246 & 59,6 \\
Age & Male & 167 & 40,0 \\
& $\leq 20$ & 171 & 41,4 \\
& $21-25$ & 215 & 52,1 \\
Education & $26-30$ & 27 & 6,5 \\
\hline Total & Vocational school & 186 & 45,0 \\
\hline \multirow{4}{*}{ Daily social media } & Faculty & 227 & 55,0 \\
usage & & $\mathbf{4 1 3}$ & $\mathbf{1 0 0 , 0}$ \\
& 1 hour or less & 38 & 9,2 \\
& $2-3$ hours & 117 & 28,3 \\
Total & $4-5$ hours & 127 & 30,8 \\
\hline & $6-7$ hours & 65 & 15,7 \\
& 8hours and more & 66 & 16,0 \\
\hline Total & & $\mathbf{4 1 3}$ & $\mathbf{1 0 0 , 0}$ \\
\hline
\end{tabular}

$55 \%$ of the respondents were students at faculty and $45 \%$ of them were students at vocational school. $30.8 \%$ of the respondents used social media between $4-5$ hours, $28.3 \%$ used social media between $2-3$ hours, $16 \%$ used social media for 8 hours and more while $15.7 \%$ spent $6-7$ hours and $9.2 \%$ spent 1 hour and less on the social media. Lastly, when the social media websites of the respondents were evaluated it was concluded that $29.8 \%$ of them preferred Instagram which was followed by Facebook with $22.9 \%$, YouTube with $17.2 \%$, Twitter with $12.5 \%$ while $9.6 \%$ chose Google+, $5 \%$ used other websites and $1.5 \%$ preferred Foursquare, $0.8 \%$ used Linkedin, $0.5 \%$ used TripAdvisor and $0.2 \%$ visited social media websites such as MySpace.

\subsection{Findings for Social Media Usage Scale}

The Social Media Usage scale was first subjected to reliability analysis and the results are shown in Table 2. The scale is not reliable with Cronbach's Alpha between 0.00 and 0.40 . If the alpha value is between 0,40 and 0,60 , the reliability of the scale is low, between 0,60 and 0,80 , the scale is quite reliable and if the scale is between 0,80 and 1,00, the scale is highly reliable (Kayış, 2014: 405). As a result of the first reliability analysis conducted on the first scale of the study, the Cronbach's Alpha coefficient of 13 items was determined to be $0.85 \%$. This value indicates that the scale is highly reliable. 
Table 2. Factor analysis of social media usage

\section{Dimensions of Social Media Usage Scale}

\begin{tabular}{|c|c|c|c|}
\hline 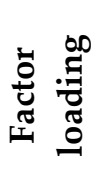 & $\sum^{\text {ฮँ }}$ & 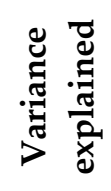 & 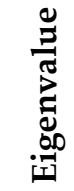 \\
\hline & 3,887 & 23,55 & 3,06 \\
\hline
\end{tabular}

\begin{tabular}{|c|c|c|c|c|}
\hline Factor 1: INVOLVEMENT & & 3,887 & 23,55 & 3,06 \\
\hline \multicolumn{5}{|l|}{ Before traveling } \\
\hline $\begin{array}{l}\text { SM_BE_3. I looked at activity/attractions reviews of other } \\
\text { travelers. }\end{array}$ & 810 & & & \\
\hline SM_BE_4 I read other travelers' experiences and tips. & 779 & & & \\
\hline $\begin{array}{l}\text { SM_BE_2. SMC2-I searched for travel information on social } \\
\text { media websites }\end{array}$ & 753 & & & \\
\hline $\begin{array}{l}\text { SM_BE_1. I read hotel reviews from other travelers } \\
\text { While traveling }\end{array}$ & ,722 & & & \\
\hline $\begin{array}{l}\text { SM_BE_5. I search for travel information on social media } \\
\text { websites (for example, things to do or where to eat) }\end{array}$ & ,580 & & & \\
\hline Factor 2: TRUST & & 3,468 & 15,61 & 2,03 \\
\hline
\end{tabular}

SM_G_15. I trust information provided by other travelers in various websites

, 726

SM_G_16. I trust information about holidays provided by social media

SM_G_14. I trust information about holidays provided by friends and relatives.

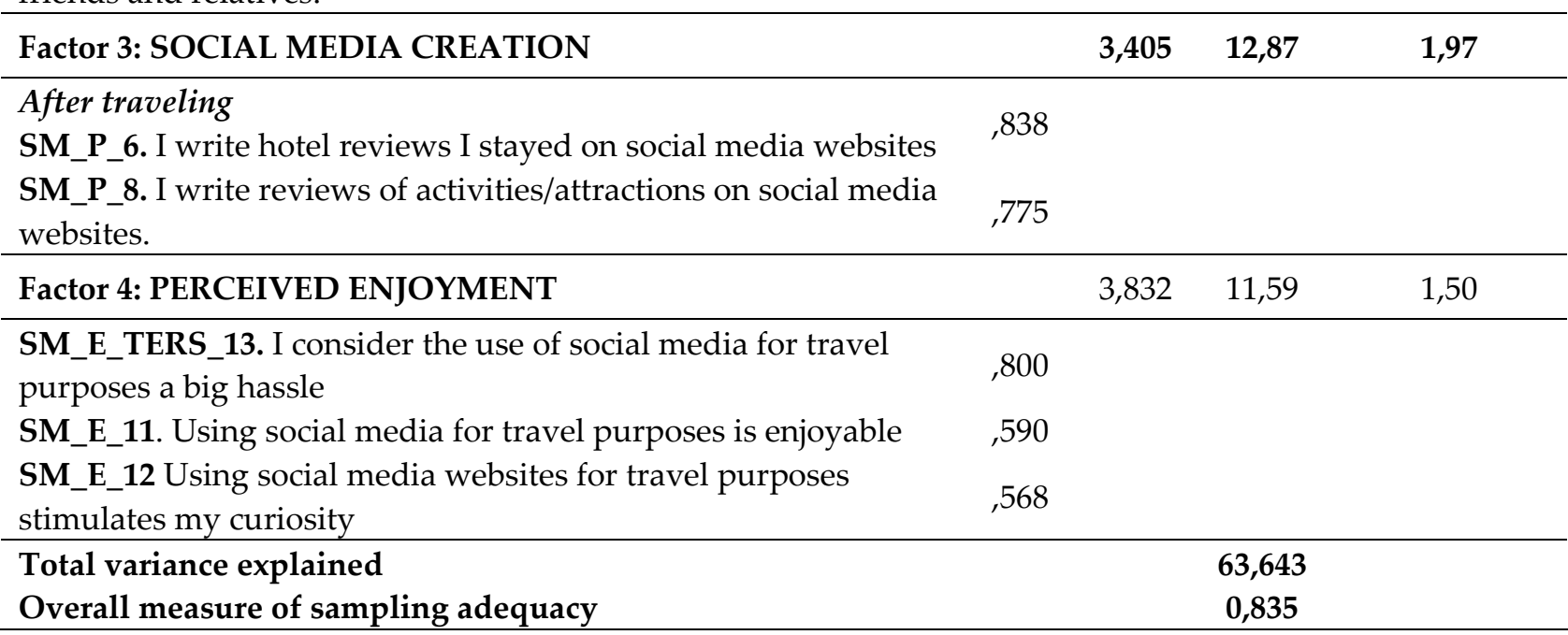

The "Social Media Usage" scale was subjected to the Kaiser-Meyer-Olkin test of sampling adequacy and Bartlett's sphericity test prior to factor analysis. Kaiser Mayer Olkin (KMO) explains whether the sample is sufficient for analysis. If the KMO is between 0 and 1 , the closer it is to 1 , the more suitable the sample is for factor analysis. The KMO value must be greater than 0.50 . The Bartlett test decides whether the data matrix is a unit matrix, whether the correlation between the variables is sufficient. The data set is suitable for factor analysis if the significance value is $<0.05$ (Sungur, 2014). As a result of the factor analysis, it was determined that the sample competence of Social Media Usage Scale was 0.835 and that the result of Bartlett's sphericity test was significant ( $<<0.05 ; \mathrm{p}:, 000)$.

As a result of the first factor analysis, it was determined that the factor loadings of some items constituting the Social Media Usage scale were not collected under one dimension and the factor loads of some items were not at the desired level. Therefore, the items found erroneous in the scale were removed and the factor analysis was repeated a few times to achieve the most appropriate factor configuration for the purpose of the study. As a result of the analysis four items (items 7, 9, 10 and 17) in the "Social Media Usage" were eliminated from 
the scale. While the first version of the scale was 17 items, after the elimination of the 4 items, the scale was formed with 13 items. The Social Media Usage Scale was collected in 4 dimensions as a result of the last factor analysis and it was determined that the percentage of the explained variance was 63,643 . Factor averages of each dimension obtained in the study for "Social Media Consumption" was 3,887, the average for 'Trust' was 3,468, the average for 'Social Media Creation' was 3.405 and the average for 'Perceived Enjoyment' was determined as 3,832 .

\subsection{Findings regarding the Social Media Involvement Scale}

As a result of the factor analysis carried out on the 'Social Media Involvement' scale, the sample adequacy of the items constituting the scale was found to be 0.873 , and the result of Bartlett's sphericity test was significant $(\mathrm{p}<0.05 ; \mathrm{p}:, 000)$.

Table 3. Factor analysis of social media involvement scale

\begin{tabular}{|c|c|c|c|c|c|}
\hline & 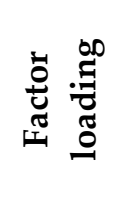 & $\stackrel{\pi}{\tilde{\Sigma}}^{\tilde{\Sigma}}$ & 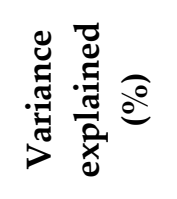 & 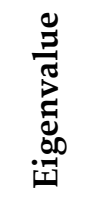 & 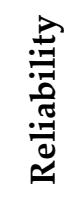 \\
\hline Factor 1: SOCIAL MEDIA INVOLVEMENT SCALE & & 3,729 & 57,49 & 4,02 & ,873 \\
\hline S_20. The use of social media means a lot to me. & ,838 & & products & & \\
\hline S_19. The use of social media is relevant & ,794 & & & & \\
\hline S_24. Use of social media is matters to me & ,792 & & & & \\
\hline S_21. Use of social media is interesting & ,789 & & & & \\
\hline S_22. Use of social media useful. & ,761 & & & & \\
\hline S_18. Use of social media is important. & ,714 & & & & \\
\hline S_23. Use of social media is vital &, 594 & & & & \\
\hline Total variance explained & & & 57,490 & & \\
\hline Overall measure of sampling adequacy & & & 0,873 & & \\
\hline
\end{tabular}

As a result of the factor analysis, the Social Media Involvement scale was formed as one-dimensional with 7 items. The percentage of the explained variance was 57,490. In addition, the 7 item reliability analysis result determined that Cronbach's Alpha coefficient was $0.87 \%$.

\subsection{Correlation Findings between the Social Media Use Scale and the Social Media Involvement Scale}

Correlation analyses for the relationship between the dimensions of the Social Media Usage Scale and the Social Media Involvement Scale have been presented in this part of the study. Correlation analysis is a statistical method used to test the linear relationship between two variables or to test the relationship of a variable with two or more variables, if any, to measure the degree of this relationship. According to the Pearson Correlation Coefficient, an interval of $0.00-0.25$ between two variables indicates that it is very weak, while a range of $0.26-0.49$ is weak, an interval of 0.50-0.69 is medium, a range of 0.70-0.89 is high and an interval of 0.90-1.00 is very high (Songur, 2014:116). 
Table 4. Correlation analysis between social media use scale dimensions and social media involvement scale

\begin{tabular}{|c|c|c|c|c|c|c|}
\hline & & 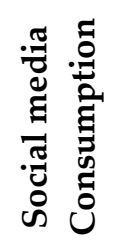 & $\underset{E}{\overrightarrow{\underline{T}}}$ & 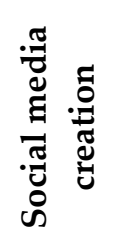 & 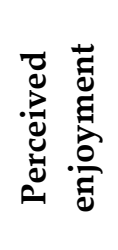 & 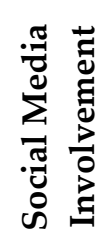 \\
\hline \multirow{2}{*}{$\begin{array}{l}\text { Social media } \\
\text { consumption }\end{array}$} & $\begin{array}{l}\text { Correlation } \\
\text { Coefficient }\end{array}$ & 1,000 &, $383^{* *}$ & $488^{* *+}$ & $408^{* *}$ &, $261^{* *}$ \\
\hline & Sig. (2-tailed) & - & ,000 & ,000 & ,000 & ,000 \\
\hline \multirow{2}{*}{ Trust } & $\begin{array}{l}\text { Correlation } \\
\text { Coefficient }\end{array}$ & ,383 & 1,000 & $434^{* *}$ & ,309** & ,308 \\
\hline & Sig. (2-tailed) & ,000 & - & ,000 & ,000 & ,000 \\
\hline \multirow{2}{*}{$\begin{array}{l}\text { Social media } \\
\text { creation }\end{array}$} & $\begin{array}{l}\text { Correlation } \\
\text { Coefficient }\end{array}$ & $488^{* *}$ &, $434^{* *}$ & 1,000 & 270 & ,283 \\
\hline & Sig. (2-tailed) & ,000 & ,000 & - & ,000 & ,000 \\
\hline \multirow{2}{*}{$\begin{array}{l}\text { Perceived } \\
\text { enjoyment }\end{array}$} & $\begin{array}{l}\text { Correlation } \\
\text { Coefficient }\end{array}$ & $408^{* *}$ &, $309^{* *}$ & $270^{* *}$ & 1,000 & ,291 \\
\hline & Sig. (2-tailed) & ,000 & ,000 & ,000 & - & ,000 \\
\hline \multirow{2}{*}{$\begin{array}{l}\text { Social Media } \\
\text { Involvement }\end{array}$} & $\begin{array}{l}\text { Correlation } \\
\text { Coefficient }\end{array}$ &, $261^{* *}$ &, $308^{* *}$ & $283^{* *}$ & ,291** & 1,000 \\
\hline & Sig. (2-tailed) & ,000 & ,000 & ,000 & ,000 & - \\
\hline
\end{tabular}

${ }^{* *} \mathrm{p}<0,05 \mathrm{~N}=(413)$

According to the first result of the analysis, it was concluded that a significant relationship existed between the Social Media Usage Scale of the Consumption dimension and the Social Media Involvement of the respondents ( $\mathrm{p}<0,05 ; \mathrm{p}:, 000)$ as well as a positive weak ( $\mathrm{r}: 261)$ relationship. Another analysis concluded that there was a significant $(\mathrm{p}<0,05 ; \mathrm{p}:, 000)$ and positive weak ( $\mathrm{r}: 308)$ relationship between the Trust dimension of the Social Media Usage Scale of the Respondents. Also there was a significant $(p<0,05 ; p:, 000)$ and positive weak ( $r$ : 283) relationship between the Social Media Creation dimension of the Social Media Usage Scale and the Social Media Involvement of the Respondents. According to another analysis, a significant ( $\mathrm{p}<0,05 ; \mathrm{p}:, 000)$ and positive weak (r: ,291) relationship was determined between the Perceived Enjoyment dimension of the Social Media Usage scale and the Social Media Involvement of respondents.

\subsection{Findings Related to Hypothesis of the Study}

The results regarding the regression analyses of the dimensions of the Social Media Usage Scale and the effect of the Social Media Involvement scale of the respondents have been presented in this part of the study. A regression analysis is a statistical method used to measure the cause and effect relationship between an independent variable and a dependent variable or more than one independent variable and a dependent variable. 
A. N. Sert $12 / 1(2020) 557-570$

Table 5. Regression Analysis Results of Respondents' Social Media Involvement and the Dimensions of Social Media Usage

\begin{tabular}{cccccccc}
\hline Independent variable & Dependent variable & $\mathbf{R}$ & $\mathbf{R}^{2}$ & $\mathbf{B}$ & Beta & Sig. & $\mathbf{F}$ \\
\hline & $\begin{array}{c}\text { Social media } \\
\text { Consumption }\end{array}$ & 0,261 & 0,068 &, 055 &, $261^{*}$ &, 000 & 29,934 \\
Respondents' Social & $\begin{array}{c}\text { Trust } \\
\text { Media Involvement }\end{array}$ & 0,308 & 0,095 &, 331 &, $308^{*}$ &, 000 & 43,050 \\
& $\begin{array}{c}\text { Social Media } \\
\text { Creation } \\
\text { Perceived }\end{array}$ & 0,283 & 0,080 &, 397 &, $283^{*}$ &, 000 & 35,791 \\
& 0,291 & 0,085 &, 304 &, $291^{*}$ &, 000 & 37,993 \\
\hline
\end{tabular}

${ }^{*} \mathrm{p}<0,05$

\section{$\mathrm{H}_{1}$ : Social media involvement affects social media consumption.}

As a result of the regression analysis, it was concluded that there is a significant $(p>0,05 ; p:, 000)$ affect relationship between the values of the Social Media Involvement of the respondents and the Social Media Consumption dimension of the Social Media Usage scale. This result shows that hypothesis H1 is supported. Furthermore, an examination of the $\mathrm{F}$ value of the regression model indicates that the Social Media Consumption of the Social Media Usage scale is explained by $30 \%$ of the respondents' Social Media Involvement.

\section{$\mathrm{H}_{2}$ : Social media involvement affects trust in the travel information source.}

As a result of another regression analysis, it was determined that was concluded that there is a significant ( $p>0,05 ; p:, 000)$ affect relationship between the Social Media Involvement of the respondents and the Trust dimension of the Social Media Usage Scale. This result shows that $\mathrm{H} 2$ hypothesis is supported. Furthermore, an examination of the $\mathrm{F}$ value of the regression model indicates that the Trust preference of the Social Media Usage scale is explained by $43 \%$ of the respondents' Social Media Involvement.

\section{$\mathrm{H}_{3}$ : Social media involvement affects the social media creation.}

As a result of another regression analysis it was concluded that there was a significant $(p<0,05 ; \mathrm{p}:, 000)$ effect relationship between the Social Media Involvement of the respondents and the Social Media creation dimension of their Social Media Involvement scale. This result shows that hypothesis H3 is supported. Furthermore, an examination of the F value of the regression model indicates that the Social Media Creation preference of the Social Media Usage scale is explained by $36 \%$ of the respondents' Social Media Involvement.

\section{$\mathrm{H}_{4}$ : Social media involvement effect the perceived enjoyment in social media usage.}

As a result of the regression analysis conducted for the last hypothesis, it was concluded that the values of the relationship between the Social Media Involvement and the Perceived Enjoyment dimension of Social Media Usage Scale of the respondents were significant ( $\mathrm{p}<0,05 ; \mathrm{p}$ :, 000$)$. This result shows that the $\mathrm{H} 4$ hypothesis is supported. Finally, an examination of the F value of the regression model indicates that the Perceived Enjoyment preference of the Social Media Usage scale is explained by 38\% of the respondents' Social Media Involvement.

\section{Conclusion}

Social media enables individuals to share their stories, experiences and interests and becoming more and more widespread, and the number of users is increasing with each day. With the spread of social media, travelrelated activities have also changed drastically, such as the ways how people get information, plan their travels and share their experiences with other potential tourists (Hays et al., 2013). In line with the incurring changes, if the how, when and where users and particularly young people are affected by social media can be fully defined, marketers can benefit from this unique interaction between the social media and consumers and help them develop marketing strategies (Hudson and Thal, 2013).

The aim of this study was to determine the influence of the social media involvement of young people in terms of traveling. According to the findings of the study, the 18-25 age group spends approximately 2-5 hours per 
day on the social media. The internet and social media play an important role in the lives of young people called digital natives as mentioned in the conceptual framework. Instagram and Facebook are the most popular social media creation websites.

As a result of the factor analysis applied to the 'Social Media Usage Scale', social media consumption, trust, social media creation and perceived enjoyment dimensions emerge. For the purpose of the study, the social media consumption dimensions reflects the extent to which individuals use social media for travel-related information while trust reflects which sources are reliable for making decisions about travel. Social media creation involves commenting on the social media related to travel, sharing photographs, etc. Perceived enjoyment covers the aspect that the use of social media for travel purposes is perceived as fun and enjoyable while social media involvement covers the general interest, commitment and point of view for travel-related social media usage.

According to the data obtained from the study, it was determined that social media was used the least during travel (activities to be done, places to go). However, it was noted that social media usage occurs mostly before travel to obtain information about travel. It was determined that the suggestions and experiences of other travelers were prioritized in particular. The findings are in parallel with other studies (Chung and Buhalis, 2008; Fotis et al., 2011; Kheiri and Nasihatkon, 2015; Amore et al., 2016). This result is important in terms of showing that social media is an important source of information for users when purchasing products and services related to tourism. The fact is that because tourism products and services cannot be evaluated beforehand like other goods and services they are considered risky. As a result, information shared by consumers is perceived as more reliable and sincere because it is generated by actual experiences and therefore personal experiences and recommendations are rather effective (Ukpabi and Karjaluoto, 2017). As a result, reading the contents of tourism products and services has become an important decision-making process.

According to the findings of the study on social media creation, it is observed that people make comments and share about their hotels during their holidays. In contrast to the previous studies (Cox et al., 2009; Fotis et al., 2011; Chung and Koo, 2015; Kheiri and Nasihatkon, 2015) the findings indicate that more comments and sharing regarding the hotels and activities are made after the travel (post travel). This can be attributed to the change in the habits of using social media creation sites over the past few years and the increasing tendency to spend more time on the social media.

In the light of the findings obtained from the study, it can be suggested that young people enjoy using social media for their travels and think that it is easy to reach the information they want on social media. The fact that young people use social media in every aspect of their lives can explain this situation. Furthermore, the fun content of social media as well as the interaction with other members causes social media to be perceived as enjoyable. Another significant finding of the study is that while young people have little confidence in their friends and relatives regarding travel preferences, they trust the information that other people put on their websites and social media the most. The findings differ from those of Cox et al. (2009), Fotis et al. (2011), Erol and Hassan (2014). These studies purported that the most trusted sources were official tourism websites, relatives and friends. The reason for the difference can be attributed to the increased use of social media in recent years, the intensification of social media usage in the marketing of tourism related products and services and the increased attractiveness of the shared content. The study also showed remarkable findings regarding the social media creation of young people.

Four hypotheses were developed and tested in the current study based on available literature and significant findings were determined regarding the effect of social media involvement on the social media usage of young people. As a result of the first hypothesis test, it was determined that social media involvement had a significant and positive effect on their choice of social media usage regarding social media consumption. In other words, social media interests and commitment lead to the selection of social media as a source of information. This is similar to the results of the studies by Leung et al. (2013), Hays et al. (2013) and Ukpabi and Karjaluoto (2017). The result of the second tested hypothesis shows that social media involvement affects the trust preference in social media usage. Social media interest and commitment increases trust in social media in the decision-making process regarding traveling. According to the result of the third hypothesis, social media involvement has been observed to affect creation preference in social media usage. Therefore, it has been determined that social media creation regarding traveling increases in parallel to the interest in the 
social media. The findings are commensurate with those in literature (Chang et al., 2016; Amaro et al., 2016). The results of the fourth tested hypothesis also revealed that social media involvement affects the choice of perceived pleasure in social media usage. The findings are similar to those of $\mathrm{Ng}$ (2016). Social media is considered as an entertainment and communication tool for young people because it offers sensory stimulation (multimedia content, interesting pictures and discussion environments, innovative ideas) to its users. Young people like to interact through social media. The pleasant feelings they gain from using social media encourages them to share interesting content.

Tourism businesses and marketers need to analyze the role of website design and mobile technology and especially social media well in order to attract and retain customers. Businesses should increase the number of social media tools they use and they should endeavor to create social media creation with content that will attract the attention and appeal to young people. It is important that the contents are prepared to enhance the sense of reality. In addition to content and creation, updating social media tools should be prioritized. Businesses should also follow the creation, complaints and suggestions made on social media and take necessary measures. Thus, the number of positive creations can be increased. In addition, when the user reviews are evaluated well, this can help in the development of touristic products and services functionality, aesthetics, design etc. and in addressing potential problems correctly, adapting to changing consumer needs and protecting market shares in a competitive environment.

Potential tourists rely on the experience of others in decision-making processes to reduce uncertainties. Accordingly, tourism stakeholders, especially marketers, need to accurately analyze the social media usage habits and reasons of their target audiences in order to make the best use of social media. Thus, they can interact more effectively with their customers and develop effective strategies. As a result, it is concluded that the obtained output contributes to understanding the effect of social media involvement of young people in terms of social media usage regarding travel.

\section{References}

Amaro, S., Duarte, P., \& Henriques, C. (2016). Travelers' Use of Social Media: A Clustering Approach. Annals of Tourism Research, 59, 1-15.

Armağan, A. (2013). Gençlerin Sanal Alanı Kullanım Tercihleri ve Kendilerini Sunum Taktikleri: Bir Araştırma. Journal of International Social Research, 6(27),: 78-92.

Ayeh, J. K., Au, N., \& Law, R. (2013). Predicting the intention to use consumer-generated media for travel planning. Tourism Management, 35(19), 132-143.

Bilgihan, A., Barreda, A., Okumus, F., \& Nusair, K. (2016). Consumer perception of knowledge-sharing in travel-related online social networks. Tourism Management, 52(1), 287-296.

Bolton, R.N., Parasuraman, A., Hoefnagels, A., Migchels, N., Kabadayi, S., Gruber, T., Loureiro, Y.K., \& Solnet, D. (2013). Understanding Generation Y and Their Use of Social Media: A Review and Research Agenda, Journal of Service Management, 24(3), 223-244.

Chung, J. Y., \& Buhalis, D. (2008). Web 2.0: A Study of Online Travel Community. In P. O'Connor, W. Hopken and U. Gretzel (Eds.), Information and Communication Technologies in Tourism 2008 (pp. 70-81). Vienna, Austria: Springer.

Chung, N., \& Koo, C. (2015). The Use of Social Media in Travel Information Search. Telematics and Informatics, 32(2), 215-229.

Chang, I., Chou, P., Yeh, K., \& Tseng, H. (2016). Factors Influencing Chinese Tourists' Intention to Use the Taiwan Medical App. Telematics Inform. 33(1), 401-409

Cohen, S. A., Prayag, G., \& Moital, M. (2014). Consumer Behaviour in Tourism: Concepts, Influences and Opportunities. Current Issues in Tourism, 17(10), 872-909.

Court, D., Elzinga, D., Mulder, S., \& Vetvik, O. J. (2009, June). The consumer decision journey. http://www.mckinseyquarterly.com/The_consumer (Date of Access: 12.09.2018). 
Cox, C., Burgess, S., Sellitto, C., \& Buultjens, J. (2009). The Role of User-Generated Content in Tourists' Travel Planning Behavior. Journal of Hospitality Marketing \& Management, 18(8), 743-764.

Durmuş, İ.B. (2014). Gençliğin Uğrak Mekânı: Sosyal Medya Gençlik ve Kültürel Mirasımız Uluslararası Kongre. Samsun: Ondokuzmayıs Üniversitesi, 131-134.

Erol, G., \& Hassan, A. (2014). Gençlerin Sosyal Medya Kullanımı ve Sosyal Medya Kullanımının Tatil Tercihlerine Etkisi. Journal of International Social Research, 7(31), 804-812.

Fotis, J., Buhalis, D., \& Rossides, N. (2011). Social Media Impact on Holiday Travel Planning: The Case of The Russian and The FSU Markets. International Journal of Online Marketing (IJOM), 1(4), 1-19.

Global Social Media Research (2018). Smart Insight. https://www.smartinsights.com/social-mediamarketing/social-media-strategy/new-global-social-media-research/ (Date of Access: 10.11.2018).

Gretzel, U. (2012). Introduction to The Section on Web 2.0 And Travellers' Behaviour. In M. Sigala, E. Christouve U. Gretzel (Eds.), Social Media in Travel, Tourism and Hospitality: Theory, Practice and Cases (pp. 167-169). Surrey: Ashgate

Hays, S., Page, S. J., \& Buhalis, D. (2013). Social Media as A Destination Marketing Tool: Its Use By National Tourism Organisations. Current Issues in Tourism, 16(3), 211-239.

Hudson, S., \& Thal, K. (2013). The Impact of Social Media on The Consumer Decision Process: Implications For Tourism Marketing. Journal of Travel \& Tourism Marketing, 30(1-2), 156-160.

Hyung-Park, D., Lee, J., \& Han, I. (2007). The effect of On-Line Consumer Reviews on Consumer Purchase Intention: The Moderating Role of Involvement. International Journal of Electronic Commerce, 11(4), 125148.

Junco, R. (2012). The Relationship Between Frequency of Facebook Use, Participation in Facebook Activities, And Student Engagement. Computers \& Education, 58(1), 162-171.

Kang, M., \& Schuett, M. A. (2013). Determinants of Sharing Travel Experiences in Social Media. Journal of Travel $\mathcal{E}$ Tourism Marketing, 30(1-2), 93-107.

Kaplan A.M., \& Hainlein M. (2010). Users of the World, Unite! The Challanges and Opportunities of Social Media, Business Horizons, 53, 59-68.

Kayış, A.(2014), Güvenilirlik Analizi, Editör: Şeref Kalaycı, SPSS Uygulamalı Çok Değişkenli İstatistik Teknikleri (ss: 401-419), 6. Baskı, Ankara, Asil Yayın Dağıtım.

Kheiri, J., \& Nasihatkon, B. (2015). Evaluating the Effects of Social Media Usage on Tourist's Behavior based on Different Phases of Travel Process. SIT Journal of Management, 5(2), 21-40.

Kim, L. H., Qu, H., \& Kim, D. J. (2009). A Study of Perceived Risk and Risk Reduction of Purchasing AirTickets Online. Journal of Travel \& Tourism Marketing, 26(3), 203-224.

Lenhart, A. (2013). Young Adults, Mobile Phones and Social Media: Technology and The Transition To Adulthood, Health, Safety $\mathcal{E}$ Well-Being of Young Adults Symposium, May 7. http://www.pewinternet.org/2013/05/07/young-adults-mobile-phones-and-social-media-technologyand-the-transition-to-adulthood/\# (Date of Access: 09.09.2018).

Leung, D., Law, R., van Hoof, H., \& Buhalis, D. (2013). Social Media in Tourism And Hospitality: A Literature Review. Journal of Travel \& Tourism Marketing, 30(1/2), 3-22.

Liberato, P., Liberato, D., Abreu, A., Alén-González, E., \& Rocha, Á. (2018). Generation Y: The Competitiveness of The Tourism Sector Based on Digital Technology. In: Antipova, T., Rocha, Á. (eds.) Information Technology Science, MOSITS 2017. Advances in Intelligent Systems and Computing, 724, sf. 227-240. Springer, Cham

$\mathrm{Ng}$, M. (2016). Factors influencing the consumer adoption of Facebook: A Two-Country Study of Youth Markets. Computers in Human Behavior, 54(1), 491-500. 
A. N. Sert $12 / 1(2020) 557-570$

Pan, B., \& Fesenmaier, D. R. (2006). Online Information Search: Vacation Planning Process. Annals of Tourism Research, 33(1), 809-832.

Pendergast, D. (2010), "Getting to know the Y Generation", in Benckendorff, P., Moscardo, G. and Pendergast, D. (Eds), Tourism and Generation Y, CABI, Wallingford, sf. 1-15.

Sirakaya, E., \& Woodside, A. G. (2005). Building and Testing Theories of Decision Making By Travellers. Tourism Management, 26(6), 815-832.

Sungur, O. (2014). Korelasyon Analizi, Editör: Şeref Kalaycı, SPSS Uygulamalı Çok Değişkenli İstatistik Teknikleri (ss: 116), 6. Baskı, Ankara, Asil Yayın Dağıtım.

Ukpabi, D. C., \& Karjaluoto, H. (2017). Consumers' Acceptance of Information and Communications Technology in Tourism: A Review. Telematics and Informatics, 34(5), 618-644.

Uşaklı, A., Koç, B., \& Sönmez, S. (2017). How 'Social' Are Destinations? Examining European DMO Social Media Usage. Journalo of Destination Marketing \& Management, 6(2), 136-149.

Vural, B., \& Bat, M. (2010). "Yeni Bir İletişim Ortamı Olarak Sosyal Medya: Ege Üniversitesi İletişim Fakültesine Yönelik Bir Araştırma", Journal of Yasar University, 20(5), 3348-3382.

Xiang, Z., \& Gretzel, U. (2010). Role of Social Media in Online Travel Information Search. Tourism Management, 31(2), 179-188. 